\title{
Reassessment of amphetamine- and phencyclidine-induced locomotor hyperactivity as a model of psychosis-like behavior in rats
}

\author{
Snezana Kusljic ${ }^{1,2,3, *}$, Maarten van den Buuse ${ }^{1,4,5,6}$, Andrea Cogos ${ }^{1,3}$ \\ ${ }^{1}$ Behavioral Neuroscience Laboratory, Mental Health Research Institute, 3052 Parkville, Australia \\ ${ }^{2}$ Department of Nursing, The University of Melbourne, 3052 Parkville, Australia \\ ${ }^{3}$ The Florey Institute of Neuroscience and Mental Health, The University of Melbourne, 3052 Parkville, Australia \\ ${ }^{4}$ School of Psychology and Public Health, La Trobe University, 3086 Melbourne, Australia \\ ${ }^{5}$ Department of Pharmacology, The University of Melbourne, 3052 Parkville, Australia \\ ${ }^{6}$ The College of Public Health, Medical and Veterinary Sciences, James Cook University, 4811 Townsville, Australia \\ *Correspondence: skusljic@unimelb.edu.au (Snezana Kusljic)
}

DOI:10.31083/j.jin2101017

This is an open access article under the CC BY 4.0 license (https://creativecommons.org/licenses/by/4.0/).

Submitted: 25 May 2021 Revised: 13 July 2021 Accepted: 12 August 2021 Published: 28 January 2022

Locomotor hyperactivity induced by psychotomimetic drugs, such as amphetamine and phencyclidine, is widely used as an animal model of psychosis-like behaviour and is commonly attributed to an interaction with dopamine release and N-methyl-D-aspartate (NMDA) receptors, respectively. However, what is often not sufficiently taken into account is that the pharmacological profile of these drugs is complex and may involve other neurotransmitter/receptor systems. Therefore, this study aimed to assess the effect of three antagonists targeting different monoamine pathways on amphetamineand phencyclidine-induced locomotor hyperactivity. A total of 32 rats were pre-treated with antagonists affecting dopaminergic, noradrenergic and serotonergic transmission: haloperidol ( $0.05 \mathrm{mg} / \mathrm{kg})$, prazosin $(2 \mathrm{mg} / \mathrm{kg})$ and ritanserin $(1 \mathrm{mg} / \mathrm{kg})$, respectively. After 30 min of spontaneous activity, rats were injected with amphetamine $(0.5 \mathrm{mg} / \mathrm{kg})$ or phencyclidine $(2.5 \mathrm{mg} / \mathrm{kg})$ and distance travelled, stereotypy and rearing recorded in photocell cages over $90 \mathrm{~min}$. Pretreatment with haloperidol or prazosin both reduced amphetamineinduced hyperactivity although pre-treatment with ritanserin had only a partial effect. None of the pre-treatments significantly altered the hyperlocomotion effects of phencyclidine. These findings suggest that noradrenergic as well as dopaminergic neurotransmission is critical for amphetamine-induced locomotor hyperactivity. Hyperlocomotion effects of phencyclidine are dependent on other factors, most likely NMDA receptor antagonism. These results help to interpret psychotomimetic drug-induced locomotor hyperactivity as an experimental model of psychosis.

Keywords

Amphetamine; Phencyclidine; Dopamine; Noradrenaline; Serotonin; Psychosis

\section{Introduction}

Psychosis is a common clinical manifestation of many psychiatric conditions including schizophrenia, bipolar disorder and depression [1]. Amphetamine and phencyclidine are psychotomimetic drugs, extensively used to study the patho- physiology of psychosis as they produce behavioral changes in animals that can model psychosis-like behaviors in humans [2]. The behavioral and biochemical effects of amphetamine and phencyclidine in animals have close parallels in humans. For example, acute administration of amphetamine and phencyclidine results in increased locomotor activity in animals and psychomotor agitation in humans $[2,3]$. In many studies, amphetamine-induced hyperactivity is used as a model of dopamine release [2] whereas the action of phencyclidine is usually assumed to be related to $\mathrm{N}$-methyl-D-aspartate (NMDA) receptor antagonism [4, 5]. However, the literature on the pharmacology of these drugs is quite inconsistent reflecting multifaceted complexities associated with psychotomimetic drug molecular actions that remain unresolved.

Some studies conclude that amphetamine-induced locomotor hyperactivity is critically dependent on dopamine release in the nucleus accumbens and can therefore be used to model a psychosis-like hyperdopaminergic state [6, 7]. These studies must be interpreted with caution as other evidence points to a variety of independent mechanisms involved in the effect of amphetamine on dopamine transmission. For example, amphetamine can reduce the release of dopamine, it can block vesicular monoamine transporter activity and activate dopamine $D_{2}$ receptor feedback inhibition [8]. Moreover, other studies show that dopamine release itself is not sufficient to elicit all amphetamine-induced behavioral responses. Amphetamine also stimulates noradrenaline and serotonin release from presynaptic terminals $[9,10]$ and serotonin $5-\mathrm{HT}_{2 A}$ receptors regulate the activation of dopaminergic neurons in the nucleus accumbens and striatum [6]. A recent study has shown that noradrenaline release from the reticular nuclei in the brainstem contributes to 
amphetamine-induced locomotor hyperactivity and stereotypy [11]. Additionally, noradrenaline and dopamine form a highly interconnected system within the central nervous system and this connectivity allows amphetamine to produce a number of behavioral effects [11].

In contrast to amphetamine, it is generally accepted that the action of phencyclidine on psychosis-like behaviors is due to NMDA receptor hypofunction $[4,5,12]$. Acute phencyclidine administration in rats produces hyperlocomotion that has translational relevance to positive symptoms in humans $[12,13]$. However, there is evidence attributing at least part of phencyclidine's action to dopaminergic, noradrenergic and serotonergic transmission [14, 15]. Several studies suggest dopaminergic involvement in hyperlocomotion effects of phencyclidine [16-19] and, according to one of these studies, phencyclidine is able to cause dysregulation in frontal dopamine release [17]. Moreover, serotonergic neurotransmission seems to be critical for the regulation of phencyclidine-induced locomotor hyperactivity [20], and phencyclidine-induced glutamate efflux in frontal cortical regions is modulated by serotonin $5 \mathrm{HT}_{2 A}$ receptors [4, 21]. Thus, it remains unclear how to interpret pharmacological mechanisms involved in the hyperlocomotion effects associated with amphetamine and phencyclidine administration.

The aim of this study was to re-evaluate dopaminergic, noradrenergic and serotonergic involvement in hyperlocomotion induced by amphetamine or phencyclidine, specifically by examining the inhibitory effects of haloperidol, prazosin and ritanserin, which target dopaminergic, noradrenergic and serotonergic activity, respectively [22-24].

\section{Materials and methods \\ 2.1 Animals}

The experimental protocol was carried out in 32 male Sprague-Dawley rats (Department of Pathology, University of Melbourne). The rats were housed under standard conditions in groups of 2-3, with free access to food and water. They were maintained on a $12 \mathrm{~h}: 12 \mathrm{~h}$ light/dark cycle (lights on at $0700 \mathrm{~h}$ ) at a constant temperature of $21 \pm 2$ ${ }^{\circ} \mathrm{C}$. One week prior to experiments, rats were handled each day over a five-day period. At the time of the first experiment, rats weighed between 250-300 g. All experiments were conducted at the Behavioral Neuroscience Laboratory at the Mental Health Research Institute (Parkville, VIC, Australia). The experimental protocol was approved by the Animal Experimentation Ethics Committee of the University of Melbourne, Australia.

\subsection{Drugs and solutions}

D-amphetamine sulfate (Sigma Chemical Co., St. Louis, MO, USA; $0.5 \mathrm{mg} / \mathrm{kg}$ ) and phencyclidine $\mathrm{HCl}$ (PCP, Sigma; $2.5 \mathrm{mg} / \mathrm{kg}$ ) were dissolved in $0.9 \%$ saline and injected subcutaneously (s.c.) in the nape of the neck using an injection volume of $1 \mathrm{~mL} / \mathrm{kg}$ of body weight. Haloperidol (Serenace ${ }^{\circledR}$, $5 \mathrm{mg}$ ampoules, Searle Laboratories, Crows Nest, NSW, Australia) was diluted to the required doses $(0.05 \mathrm{mg} / \mathrm{kg})$ in saline; vehicle treatment was saline. Prazosin (Sigma) was dissolved in hot water and then diluted to $2 \mathrm{mg} / \mathrm{kg}$ in saline, while ritanserin (Sigma) was dissolved in DMSO (1\%) and then diluted in saline to give a dose of $1 \mathrm{mg} / \mathrm{kg}$; vehicle treatment consisted of half the rats receiving saline and half receiving $1 \%$ DMSO in saline. The three drugs were administered intraperitoneally (i.p.) in an injection volume of 1 $\mathrm{mL} / \mathrm{kg}$ of body weight. The dose selection for each drug was based on the unpublished and published work completed in our laboratory [25-27] as well as the literature [23, 24].

\subsection{Behavioral testing}

All experiments were carried out in the morning between 08:30 and 11:30. To minimise the impact of circadian rhythms on drug action, the same time of the light phase i.e., morning was chosen for the study. The study included 4 groups of $n=8$ rats/group; 2 groups were treated with amphetamine and 2 groups with phencyclidine. Using a repeated-measures design, these groups were randomly pretreated with either (1) vehicle and haloperidol $(0.05 \mathrm{mg} / \mathrm{kg})$, or (2) vehicle, prazosin $(2 \mathrm{mg} / \mathrm{kg})$ and ritanserin $(1 \mathrm{mg} / \mathrm{kg})$, before being treated with amphetamine or phencyclidine, with 3 days clearance allowed between each pre-treatment. Rats were pre-treated i.p. with either vehicle or drug 15 min before being placed in the photocell cages. After 30 min of spontaneous activity in the photocell cages, rats were injected with either $0.5 \mathrm{mg} / \mathrm{kg}$ amphetamine or $2.5 \mathrm{mg} / \mathrm{kg}$ phencyclidine and behavioral responses recorded over a further $90 \mathrm{~min}$. Behavioral responses such as distance travelled, stereotypy and vertical counts/rearing were monitored using eight automated photocell cages $(43 \times 43 \times 31 \mathrm{~cm}$, ENV520, MED Associates, St. Albans, VT, USA) as previously described $[20,26]$. Briefly, the position of the rat at any time was detected with sixteen evenly-spaced infrared sources and sensors on each of the four sides of the monitor. These infrared sources/sensors form an array of invisible (virtual) boxes that have a dimension of $4 \times 4$ sources/sensors $(\sim 10.75$ $\times 10.75 \mathrm{~cm}$ ). Stereotypy, which is considered repetitive behaviours such as circling and head weaving, was automatically determined by the system as small, repetitive beam breaks within a virtual box of $4 \times 4$ sources/sensors around the rat. The addition of a photobeam array above a rat added a second plane of detection to the system to detect rearing i.e., vertical beam breaks or vertical counts. Every $50 \mathrm{msec}$, the software checked for the presence or absence of the infrared beam at each sensor, allowing to very precisely track the movement of a rat.

\subsection{Data analysis}

Data were expressed as the mean \pm the standard error of the mean (SEM). All data were analyzed with analysis of variance (ANOVA) with repeated measures where appropriate, using the statistical software package SYSTAT 13.0 (SPSS Inc., Chicago, IL, USA). Data were considered significant at $p<0.05$. Locomotor activity data were summed in 30 min blocks (baseline, 30 min of pre-treatment only; 0-30 
min, 30-60 min and 60-90 min blocks are pre-treatment and treatment) and these four blocks ('Time'; repeated measures) were used to assess the main effect of 'Pre-treatment' (vehicle, haloperidol, prazosin and ritanserin), on amphetamineor phencyclidine-induced locomotor hyperactivity. The 510 min interval during which rats were removed from locomotor monitors to be injected was excluded from data analysis; all other data was included. For significant 'pre-treatment $x$ time' interactions, post-hoc tests consisted of further pairwise ANOVAs comparing vehicle and pre-treatment for each 30 min block. ANOVA comparing the effects of vehicle, prazosin and ritanserin pre-treatment on amphetamineinduced locomotor hyperactivity revealed a main effect of pre-treatment $\left(\mathrm{F}_{2,14}=12.5, p=0.001\right)$, thus we separated the pre-treatments in the Results. Effect size is estimated with partial eta squared ( $\eta^{2}$; IBM SPSS Statistics 26.0, (IBM Corp., Chicago, IL, USA)), where $\eta^{2}=0.01$ indicates a small effect, $\eta^{2}=0.06$ a medium effect and $\eta^{2}=0.14$ a large effect.

\section{Results \\ 3.1 Haloperidol - amphetamine}

When analyzing the time course of distance travelled, there was a significant pre-treatment $\times$ time interaction $\left(\mathrm{F}_{3,21}=4.9, p=0.010, \eta^{2}=0.41\right)$ as well as main effects of haloperidol pre-treatment $\left(\mathrm{F}_{1,7}=6.4, p=0.04, \eta^{2}=0.48\right)$ and of time $\left(\mathrm{F}_{3,21}=34.9, p<0.001, \eta^{2}=0.83\right)$. These results reflect a significant reduction in amphetamine-induced distance travelled caused by haloperidol (Fig. 1A). When comparing vehicle and $0.05 \mathrm{mg} / \mathrm{kg}$ haloperidol at each $30 \mathrm{~min}$ time block, haloperidol pre-treatment significantly reduced amphetamine-induced hyperactivity at the $0-30$ and 30-60 min time blocks $\left(\mathrm{F}_{1,7}=17.0, p=0.004, \eta^{2}=0.71\right.$ and $\mathrm{F}_{1,7}$ $=6.1, p=0.042, \eta^{2}=0.47$, respectively) but not at the $60-90$ min block (Fig. 1A). Furthermore, haloperidol did not significantly reduce baseline.

Analysis of stereotypic scores supported the distance travelled findings. There was a pre-treatment $\times$ time interaction $\left(\mathrm{F}_{3,21}=3.8, p=0.04, \eta^{2}=0.33\right)$ as well as a main effect of time $\left(\mathrm{F}_{3,21}=41.7, p<0.001, \eta^{2}=0.86\right)$, reflecting a haloperidolinduced reduction in amphetamine-induced stereotypy at the $0-30$ and 30-60 min time blocks only $\left(\mathrm{F}_{1,7}=5.7, p=0.05\right.$, $\eta^{2}=0.45$ and $\mathrm{F}_{1,7}=5.3, p=0.05, \eta^{2}=0.43$, respectively; Fig. 2A). Similarly, when analyzing vertical scores, there was a significant pre-treatment $\times$ time interaction $\left(F_{3,21}=4.8\right.$, $\left.p=0.01, \eta^{2}=0.41\right)$ as well as main effects of pre-treatment $\left(\mathrm{F}_{1,7}=5.0, p=0.06, \eta^{2}=0.42\right)$ and of time $\left(\mathrm{F}_{3,21}=50.9\right.$, $\left.p<0.001, \eta^{2}=0.88\right)$. The significant interaction was due to a haloperidol-induced reduction in amphetamine-induced rearing at the $0-30$ and 30-60 min time blocks only $\left(\mathrm{F}_{1,7}=\right.$ 6.8, $p=0.04, \eta^{2}=0.49$ and $\mathrm{F}_{1,7}=6.0, p=0.04, \eta^{2}=0.46$, respectively; Table 1 ).

\subsection{Haloperidol-phencyclidine}

Analysis of the time course of distance travelled revealed a main effect of time $\left(F_{3,21}=27.6, p<0.001, \eta^{2}=0.80\right)$ reflecting an increase in distance travelled after phencycli-
Table 1. Cumulative vertical counts after treatment with amphetamine and phencyclidine.

\begin{tabular}{lcc}
\hline & Amphetamine & Phencyclidine \\
\hline Vehicle & $2060 \pm 206$ & $710 \pm 170$ \\
Haloperidol & $1452 \pm 118^{*}$ & $503 \pm 108$ \\
\hline Vehicle & $1730 \pm 290$ & $726 \pm 119$ \\
Prazosin & $697 \pm 233^{*}$ & $575 \pm 132$ \\
Ritanserin & $1702 \pm 264$ & $957 \pm 231^{*}$ \\
\hline
\end{tabular}

Rats were pre-treated with vehicle, haloperidol $(0.05 \mathrm{mg} / \mathrm{kg})$, prazosin $(2 \mathrm{mg} / \mathrm{kg})$ or ritanserin $(1 \mathrm{mg} / \mathrm{kg})$ and vertical counts/rearing were obtained during $90 \mathrm{~min}$ after injection of amphetamine $(0.5 \mathrm{mg} / \mathrm{kg})$ or phencyclidine $(2.5$ $\mathrm{mg} / \mathrm{kg}$ ). Differences between pre-treatments were analyzed by ANOVA. Data are expressed as total counts (group average) \pm SEM. ${ }^{*} p<0.05$ compared to vehicle pre-treatment.

dine. There was no significant main effect of haloperidol pretreatment or pre-treatment $\times$ time interaction, reflecting a lack of effect of $0.05 \mathrm{mg} / \mathrm{kg}$ haloperidol on phencyclidineinduced hyperactivity (Fig. 1B), despite this dose being effective against amphetamine-induced hyperactivity. Similarly, when analyzing stereotypic and vertical scores, there was a main effect of time $\left(\mathrm{F}_{3,21}=38.3, p<0.001, \eta^{2}=0.85\right.$ and $\mathrm{F}_{3,21}=6.5, p=0.003, \eta^{2}=0.48$, respectively), but no other significant effects, again confirming the lack of effect of haloperidol on phencyclidine-induced hyperactivity (Fig. 2B; Table 1).

\subsection{Prazosin-amphetamine}

Analysis of distance travelled showed a significant pretreatment $\times$ time interaction $\left(\mathrm{F}_{3,21}=7.2, p=0.002, \eta^{2}=\right.$ $0.51)$ and main effects of prazosin pre-treatment $\left(\mathrm{F}_{1,7}=13.5\right.$, $\left.p=0.008, \eta^{2}=0.66\right)$ and time $\left(\mathrm{F}_{3,21}=16.0, p<0.001, \eta^{2}=\right.$ $0.70)$. When comparing vehicle and prazosin at each $30 \mathrm{~min}$ time block, they all showed a significant prazosin-induced reduction in distance travelled (baseline: $\mathrm{F}_{1,7}=12.5, p=0.01$, $\eta^{2}=0.64 ; 0-30 \mathrm{~min}: \mathrm{F}_{1,7}=12.2, p=0.01, \eta^{2}=0.64 ; 30-60$ min: $F_{1,7}=10.4, p=0.015, \eta^{2}=0.60 ; 60-90 \min : F_{1,7}=15.6$, $p=0.006, \eta^{2}=0.69$ ) (Fig. 1C).

There were significant main effects of prazosin pretreatment $\left(\mathrm{F}_{1,7}=8.8, p=0.021, \eta^{2}=0.56\right)$ and time $\left(\mathrm{F}_{3,21}\right.$ $\left.=15.9, p<0.001, \eta^{2}=0.69\right)$ on stereotypy scores, but no pre-treatment $\times$ time interaction, suggesting that prazosin pre-treatment reduced stereotypy regardless of the presence of amphetamine (Fig. 2C). In regards to vertical scores, there was a significant pre-treatment $\times$ time interaction $\left(\mathrm{F}_{3,21}=\right.$ 8.3, $\left.p=0.001, \eta^{2}=0.54\right)$ and main effects of prazosin pretreatment $\left(\mathrm{F}_{1,7}=18.9, p=0.003, \eta^{2}=0.73\right)$ and time $\left(\mathrm{F}_{3,21}\right.$ $\left.=14.5, p<0.001, \eta^{2}=0.68\right)$. When comparing vehicle and prazosin at each time block, prazosin pre-treatment did not alter baseline rearing, but did reduce amphetamine-induced rearing (0-30 min: $\mathrm{F}_{1,7}=21.5, p=0.002, \eta^{2}=0.75 ; 30-60$ min: $\mathrm{F}_{1,7}=12.4, p=0.01, \eta^{2}=0.64 ; 60-90 \mathrm{~min}: \mathrm{F}_{1,7}=23.6$, $p=0.002, \eta^{2}=0.77$. 

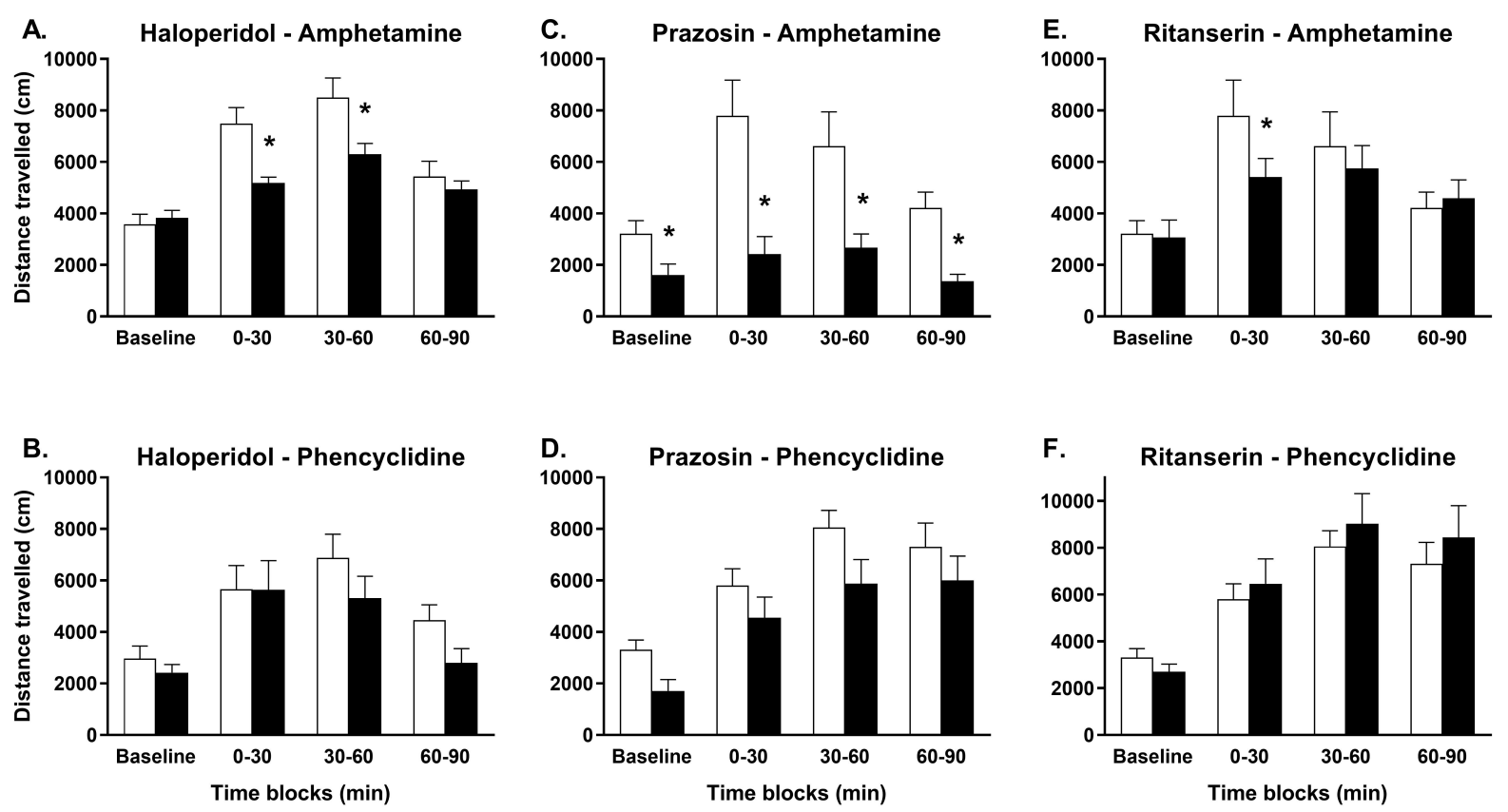

Fig. 1. Distance travelled after amphetamine (top panels: A, C, E) or phencyclidine (bottom panels: B, D, F) in rats pre-treated with vehicle (white bars) or psychotomimetic-drug (black bars; A, B: haloperidol $0.05 \mathrm{mg} / \mathrm{kg}$, C, D: prazosin $2 \mathrm{mg} / \mathrm{kg}$, E, F: ritanserin $1 \mathrm{mg} / \mathrm{kg}$ ). Spontaneous activity ('Baseline') was recorded for $30 \mathrm{~min}$ before rats were injected with amphetamine $(0.5 \mathrm{mg} / \mathrm{kg})$ or phencyclidine $(2.5 \mathrm{mg} / \mathrm{kg})$ and activity recorded for a further $90 \mathrm{~min}$ (time blocks: 0-30 $\mathrm{min}, 30-60 \mathrm{~min}, 60-90 \mathrm{~min}$ ). Bars represent total distance travelled in $30 \mathrm{~min}$ (group average; $\mathrm{cm}$ ) $\pm \mathrm{SEM} ;{ }^{*} p<0.05$ compared to vehicle pre-treatment of that time block (this analysis was only done if there was a significant pre-treatment $\times$ time interaction).

\subsection{Prazosin- phencyclidine}

There were significant main effects of prazosin pretreatment $\left(\mathrm{F}_{1,7}=7.1, p=0.032, \eta^{2}=0.50\right)$ and time $\left(\mathrm{F}_{3,21}\right.$ $\left.=45.9, p<0.001, \eta^{2}=0.87\right)$ on distance travelled, but no pre-treatment $\times$ time interaction. This suggests that the reduction in distance travelled caused by $2 \mathrm{mg} / \mathrm{kg}$ prazosin occurred similarly with or without phencyclidine treatment (Fig. 1D).

Analysis of stereotypy scores showed a significant pretreatment $\times$ time interaction $\left(\mathrm{F}_{3,21}=7.6, p=0.001, \eta^{2}=\right.$ $0.52)$, a trend for a main effect of prazosin pre-treatment $\left(\mathrm{F}_{1,7}\right.$ $\left.=5.6, p=0.05, \eta^{2}=0.44\right)$, and a significant main effect of time $\left(\mathrm{F}_{3,21}=47.5, p<0.001, \eta^{2}=0.87\right)$. Further analysis of the interaction revealed a significant effect of prazosin pretreatment on baseline $\left(\mathrm{F}_{1,7}=19.4, p=0.003, \eta^{2}=0.74\right)$ but no effect on the phencyclidine-induced increase in stereotypy scores (Fig. 2D). When analyzing vertical scores, there was a significant main effect of time $\left(\mathrm{F}_{3,21}=18.1, p<0.001, \eta^{2}\right.$ $=0.72$ ), but no other significant effects, suggesting that prazosin pre-treatment had no effect on rearing (Table 1).

\subsection{Ritanserin-amphetamine}

When analyzing distance travelled, there was a significant pre-treatment $\times$ time interaction $\left(\mathrm{F}_{(3,21)}=4.5, p=\right.$ $\left.0.014, \eta^{2}=0.39\right)$, a main effect of time $\left(\mathrm{F}_{3,21}=17.7, p\right.$ $<0.001, \eta^{2}=0.72$ ), but no significant main effect of ritanserin pre-treatment (Fig. 1E). Comparing vehicle and 1 $\mathrm{mg} / \mathrm{kg}$ ritanserin at each time block revealed that ritanserin pre-treatment did not alter baseline, but significantly reduced amphetamine-induced hyperactivity at the 0-30 min time block only $\left(\mathrm{F}_{1,7}=7.6, p=0.028, \eta^{2}=0.52\right)$.

Analysis of stereotypy scores revealed a main effect of time $\left(\mathrm{F}_{3,21}=21.2, p<0.001, \eta^{2}=0.75\right)$, but no significant main effect of ritanserin pre-treatment or a time $\times$ pre-treatment interaction suggesting that ritanserin did not affect stereotypy (Fig. 2D). When analyzing vertical scores, there was a main effect of time $\left(\mathrm{F}_{3,21}=30.7, p<0.001, \eta^{2}=0.81\right)$, and a weak pre-treatment $\times$ time interaction $\left(\mathrm{F}_{3,21}=3.1\right.$, $p=0.047, \eta^{2}=0.31$ ), but no significant main effect of ritanserin pre-treatment (Table 1). Further analysis of the interaction revealed a trend for a reduction in amphetamineinduced rearing occurred at the $0-30 \mathrm{~min}$ time block $\left(\mathrm{F}_{1,7}=\right.$ 5.0, $p=0.06, \eta^{2}=0.42$ ).

\subsection{Ritanserin - phencyclidine}

Analysis of distance travelled revealed a main effect of time $\left(\mathrm{F}_{3,21}=27.5, p<0.001, \eta^{2}=0.80\right)$ but no other significant effects, suggesting that $1 \mathrm{mg} / \mathrm{kg}$ ritanserin had no effect on baseline or phencyclidine-induced distance travelled (Fig. 1F).

Analysis of stereotypy scores revealed a pre-treatment $x$ time interaction $\left(\mathrm{F}_{3,21}=3.9, p=0.024, \eta^{2}=0.36\right)$ and a main effect of time $\left(\mathrm{F}_{3,21}=32.1, p<0.001, \eta^{2}=0.82\right)$, but no significant main effect of ritanserin pre-treatment (Fig. 2F). 

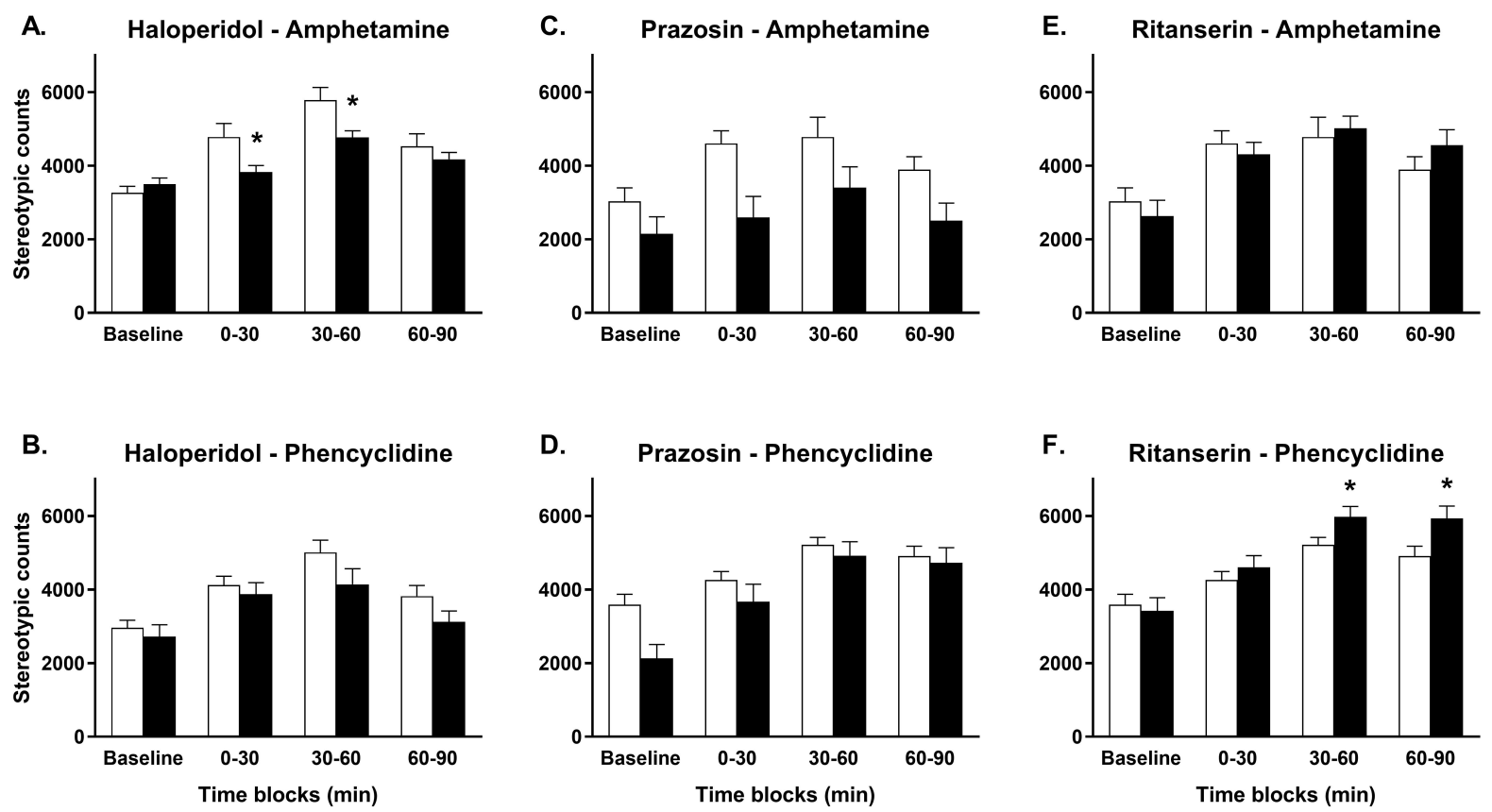

Fig. 2. Stereotypic counts after amphetamine (top panels: A, C, E) or phencyclidine (bottom panels: B, D, F) in rats pre-treated with vehicle (white bars) or psychotomimetic-drug (black bars; A, B: haloperidol $0.05 \mathrm{mg} / \mathrm{kg}$, C, D: prazosin $2 \mathrm{mg} / \mathrm{kg}$, E, F: ritanserin $1 \mathrm{mg} / \mathrm{kg}$ ). Spontaneous activity ('Baseline') was recorded for $30 \mathrm{~min}$ before rats were injected with amphetamine $(0.5 \mathrm{mg} / \mathrm{kg})$ or phencyclidine $(2.5 \mathrm{mg} / \mathrm{kg})$ and activity recorded for a further 90 min (time blocks: 0-30 min, 30-60 min, 60-90 min). Bars represent total stereotypic counts in 30 min (group average) \pm SEM; ${ }^{*} p<0.05$ compared to vehicle pre-treatment of that time block (this analysis was only done if there was a significant pre-treatment $\times$ time interaction).

When comparing vehicle and ritanserin at each time block, ritanserin pre-treatment did not alter baseline stereotypy, but did enhance phencyclidine-induced stereotypy (30-60 min: $\mathrm{F}_{1,7}=7.0, p=0.033, \eta^{2}=0.50 ; 60-90 \mathrm{~min}: \mathrm{F}_{1,7}=12.0, p=$ $\left.0.011, \eta^{2}=0.63\right)$. Similarly, when analyzing vertical scores, there was a pre-treatment $\times$ time interaction $\left(\mathrm{F}_{3,21}=3.3, p\right.$ $\left.=0.04, \eta^{2}=0.32\right)$ and a main effect of time $\left(\mathrm{F}_{3,21}=11.7, p\right.$ $<0.001, \eta^{2}=0.63$; Table 1$)$. Further analysis of the interaction revealed there was only a trend for ritanserin to enhance phencyclidine-induced rearing at the 60-90 min time block $\left(\mathrm{F}_{1,7}=4.0, p=0.087, \eta^{2}=0.36\right)$.

\section{Discussion}

In this study, we used three different antagonists to evaluate their inhibitory effects on amphetamine- and phencyclidine-induced locomotor hyperactivity. The principal findings of this study were that: (1) amphetamineinduced locomotor hyperactivity was attenuated by pretreatment with haloperidol and prazosin; (2) amphetamineinduced locomotor hyperactivity was partially reduced by ritanserin; (3) phencyclidine-induced locomotor hyperactivity was not affected by either antagonist. These findings suggest that dopaminergic as well as noradrenergic neurotransmission is critical for the regulation of hyperlocomotion effects of amphetamine while phencyclidine-induced hyperactivity is dependent on other factors, most likely NMDA receptor antagonism or other not yet known mechanisms but, importantly, not dopaminergic or noradrenergic mechanisms.

Psychotomimetic drug-induced locomotor hyperactivity is generally attributed to limbic-striatal modulation of brainstem motor circuits [2]. Classic micro-injection and lesion studies have highlighted the role of dopamine in the nucleus accumbens (ventral striatum) in modulating the ambulatory locomotor response to amphetamine, while dopamine in the caudate putamen (dorsal striatum) is instead involved in the stereotypy/rearing induced by amphetamine [28-31]. The nucleus accumbens is an important regulatory interface between limbic and motor systems in driving adaptive behavior through inputs from the prefrontal cortex, hippocampus and amygdala, and outputs to the ventral pallidum and substantia nigra [32]. Recent advances in human neuroimaging techniques call into question the involvement of the mesolimbic system in relation to psychotic symptoms and instead point to the importance of dopaminergic nigrostriatal pathways, specifically in the dorsal striatum $[33,34]$.

Haloperidol, the predominantly dopamine $\mathrm{D}_{2}$ receptor antagonist, and prazosin, an adrenergic $\alpha_{1}$ receptor antagonist, attenuated amphetamine-induced locomotor hyperactivity, including distance travelled, stereotypy and rearing. While the present study found that prazosin reduced baseline activity, suggesting that some of its effect on amphetamine may be due to non-specific effects, importantly, prazosin also 
significantly attenuated amphetamine-induced ambulatory locomotion. This is consistent with literature showing that haloperidol reverses hyperlocomotion $[35,36]$ and prazosin attenuates locomotor hyperactivity induced by amphetamine [37] or methamphetamine [38, 39]. In terms of rearing, it was expected that haloperidol pre-treatment would reduce amphetamine-induced rearing given haloperidol's mechanism of action and the role of dopamine in mediating hyperlocomotion/rearing. The attenuation of amphetamineinduced hyperlocomotion/rearing by prazosin may be attributed to the activation of postsynaptic adrenergic $\alpha_{1}$ receptors and the strong interplay between noradrenaline and dopamine in amphetamine-induced behaviors [11, 38]. For example, noradrenergic axons from the locus coeruleus regulate dopamine release throughout the brain, including the ventral striatum and dorsal striatum [11]. The (partial) effect of ritanserin on amphetamine-induced locomotor hyperactivity and no effect on rearing is in line with earlier studies showing that $5-\mathrm{HT}_{2 A}$ receptors modulate dopamine release in the nucleus accumbens and ventral striatum [6] and that a specific serotonin $5 \mathrm{HT}_{2 A}$ receptor antagonist (SR46349B) inhibited amphetamine-induced hyperactivity in rats [38, 39].

Our findings suggest a complex overlap of dopaminergic $\mathrm{D}_{2}$ and adrenergic $\alpha_{1}$ receptors in the brain in the hyperlocomotion effects of amphetamine. High levels of dopamine $\mathrm{D}_{2}$ receptors are found in the striatum, nucleus accumbens and olfactory tubercle [40], whereas high levels of adrenergic $\alpha_{1}$ receptors are located in hypothalamic nuclei, substantia nigra, but also in the nucleus accumbens [41]. It was shown that dopamine release is controlled by noradrenaline stimulation of $\alpha_{1}$ adrenergic receptors in the prefrontal cortex [42] and that stimulation of postsynaptic adrenergic $\alpha_{1 b}$ receptors increases dopamine-mediated locomotor responses [43]. Thus, activation of $\alpha_{1 b}$ adrenoceptors by noradrenaline in the frontal cortex modulates dopamine release in the nucleus accumbens and thus hyperlocomotion effects of amphetamine. The effect of prazosin in the present study could be explained by an action on this frontal cortical pathway. However, an alternative, or additional mechanism by which $\alpha_{1}$ receptors may be involved in amphetamine locomotor hyperactivity is by a more direct interaction in the nucleus accumbens $[37,44,45]$. Both $\alpha_{1}$ receptors located presynaptically on noradrenergic terminals in the nucleus accumbens as well as $\alpha_{1}$ receptors located postsynaptically from these terminals, are involved in the regulation of dopamine release [46]. Blockade of the receptors by prazosin could then inhibit evoked dopamine release [46] and, hence, the effect of amphetamine [45].

The effect of ritanserin via $5-\mathrm{HT}_{2 A}$ receptor antagonism is most likely located in the basal ganglia where these receptors are found in high levels [47]. It cannot be excluded that the lack of complete inhibition by ritanserin could be due to the dose being too low to occupy adequate level of $5 \mathrm{HT}_{2 \mathrm{~A} / 2 \mathrm{C}}$ receptors and/or a possibility of 'wearing off' effect (signifi- cantly inhibited amphetamine's effects during the 0-30 min time block only). Future studies should examine different doses of acutely administered ritanserin on amphetamineinduced hyperlocomotion as well as the kinetics of ritanserin including its metabolism and elimination, to establish the role of serotonergic transmission in amphetamine-induced hyperlocomotion.

In contrast to amphetamine, phencyclidine-induced hyperactivity was not affected by any of the three antagonists used. Given that dopamine $\mathrm{D}_{2}$, adrenergic $\alpha_{1}$, or serotonin $5-\mathrm{HT}_{2 A / 2 C}$ receptor antagonism did not markedly alter phencyclidine-induced hyperactivity, the role of glutamate NMDA receptors in phencyclidine's action remains the dominating hypothesis for now. However, there may be other mechanisms not yet known involved. Hence, to rule out or confirm selective NMDA receptor involvement, future studies must consider including glutamate NMDA receptor agonists/antagonists in the pharmacological profiling of phencyclidine-induced locomotor hyperactivity. There was, however, a slight effect for ritanserin to enhance phencyclidine-induced stereotypy and rearing. This finding is in line with the above-mentioned notion that other mechanisms including serotonin-glutamate interactions may be involved [26]. Given that stereotypy/rearing, but not distance travelled, were affected by ritanserin, it is possible that the dorsal striatum rather than the ventral striatum is involved, however further studies are required. Moreover, this highlights that distance travelled, stereotypy and rearing may all have different brain regions and circuitry governing them and, consequently, different pharmacology.

There are several limitations of this study. Firstly, only male rats were used in this study. Given that we and others have shown sex differences in psychotomimetic-induced behaviors in animals [48, 49], future studies should include both male and female rats. Second, future studies should consider circadian rhythms and whether testing should occur during the light or dark phase. However, doses of amphetamine (0.6 $\mathrm{mg} / \mathrm{kg}$ ) similar to that used in this study were found to increase locomotor activity regardless of the large difference in baseline activity between the light and dark phases [50]. Third, the locomotor photocell system automatically measured 'stereotypy' as any repetitive beam breaks within a virtual box, however the exact behaviour within the virtual box, such as circling and/or head weaving, was not well-defined. Finally, we have not directly examined NMDA receptor antagonism in phencyclidine-induced behaviours, hence, at this stage we can only assume that NMDA receptor hypoactivity is involved. Future research should use selective NMDA receptor agonists and antagonists to dissociate the role of glutamatergic NMDA receptors in phencyclidine-induced locomotor hyperactivity.

\section{Conclusions}

This study shows that the noradrenergic, as well as the dopaminergic system, is involved in mediating 
amphetamine- but not phencyclidine-induced locomotor hyperactivity. In addition to dopamine $\mathrm{D}_{2}$ and adrenergic $\alpha_{1}$ receptors, our study showed that serotonin $5-\mathrm{HT}_{2 A / 2 C}$ receptors also play a small role in amphetamine-induced hyperactivity. By contrast, hyperlocomotion induced by phencyclidine is likely dependent on NMDA receptors. Future studies should explore the role of other neurotransmitter systems, such as the cholinergic system [11], in mediating the locomotor effects induced by amphetamine and phencyclidine. These findings highlight the complex pharmacology involved in the commonly-used psychosis model of psychotomimetic drug-induced locomotor hyperactivity, and suggest caution is warranted in the interpretation of the neurotransmitterreceptor systems involved.

\section{Abbreviations}

ANOVA, analysis of variance; DMSO, dimethyl sulfoxide; $\mathrm{HCl}$, hydrochloric acid; NMDA, N-methyl-D-aspartate.

\section{Author contributions}

SK and MvdB designed the research study. SK performed the research. AG analyzed the data. SK and AG wrote the manuscript. All authors contributed to editorial changes in the manuscript. All authors read and approved the final manuscript.

\section{Ethics approval and consent to participate}

Animals were raised and handled at the Department of Pathology, the University of Melbourne, Melbourne, Australia until 5 weeks of age. They were then transferred to the Behavioral Neuroscience Laboratory at the Mental Health Research Institute in Melbourne (Parkville, VIC Australia) where all experiments were conducted. The experimental protocol was approved by the Animal Experimentation Ethics Committee of the University of Melbourne, Melbourne, Australia (AEEC \#01159). All scientific procedures using animals were carried out in accordance with the Prevention of Cruelty to Animals Act 1986 and the Australian code of practice for the care and use of animals for scientific purposes (1997).

\section{Acknowledgment}

We thank all the reviewers for their constructive feedback.

\section{Funding}

This research was part-funded by the National Health and Medical Research Council of Australia (AG CDF 1108098, Project Grant 509234). The Florey Institute of Neuroscience and Mental Health acknowledges the funding from the Victorian Government's Operational Infrastructure Support.

\section{Conflict of interest}

The authors declare no conflict of interest.

\section{References}

[1] Stanghellini G, Raballo A. Differential typology of delusions in major depression and schizophrenia. A critique to the unitary concept of 'psychosis'. Journal of Affective Disorders. 2015; 171: 171178.

[2] van den Buuse M. Modeling the Positive Symptoms of Schizophrenia in Genetically Modified Mice: Pharmacology and Methodology Aspects. Schizophrenia Bulletin. 2010; 36: 246-270.

[3] van den Buuse M, Garner B, Gogos A, Kusljic S. Importance of animal models in schizophrenia research. Australian and New Zealand Journal of Psychiatry. 2005; 39: 550-557.

[4] Adams B, Moghaddam B. Corticolimbic dopamine neurotransmission is temporally dissociated from the cognitive and locomotor effects of phencyclidine. Journal of Neuroscience. 1998; 18: 5545-5554.

[5] Jentsch J. The Neuropsychopharmacology of Phencyclidine from NMDA Receptor Hypofunction to the Dopamine Hypothesis of Schizophrenia. Neuropsychopharmacology. 1999; 20: 201-225.

[6] Porras G, Di Matteo V, Fracasso C, Lucas G, De Deurwaerdère P, Caccia $\mathrm{S}$, et al. 5-HT2a and 5-HT2C/2B receptor subtypes modulate dopamine release induced in vivo by amphetamine and morphine in both the rat nucleus accumbens and striatum. Neuropsychopharmacology. 2002; 26: 311-324.

[7] Sulzer D, Sonders MS, Poulsen NW, Galli A. Mechanisms of neurotransmitter release by amphetamines: a review. Progress in Neurobiology. 2005; 75: 406-433.

[8] Sulzer D. How addictive drugs disrupt presynaptic dopamine neurotransmission. Neuron. 2011; 69: 628-649.

[9] Kuczenski R, Segal DS, Cho AK, Melega W. Hippocampus norepinephrine, caudate dopamine and serotonin, and behavioral responses to the stereoisomers of amphetamine and methamphetamine. Journal of Neuroscience. 1995; 15: 1308-1317.

[10] Rothman RB, Baumann MH, Dersch CM, Romero DV, Rice KC, Carroll FI, et al. Amphetamine-type central nervous system stimulants release norepinephrine more potently than they release dopamine and serotonin. Synapse. 2001; 39: 32-41.

[11] Ferrucci M, Limanaqi F, Ryskalin L, Biagioni F, Busceti CL, Fornai F. The Effects of Amphetamine and Methamphetamine on the Release of Norepinephrine, Dopamine and Acetylcholine from the Brainstem Reticular Formation. Frontiers in Neuroanatomy. 2019; 13: 48 .

[12] Winship IR, Dursun SM, Baker GB, Balista PA, Kandratavicius L, Maia-de-Oliveira JP, et al. An Overview of Animal Models Related to Schizophrenia. The Canadian Journal of Psychiatry. 2019; 64: 5-17.

[13] Kalinichev M, Robbins MJ, Hartfield EM, Maycox PR, Moore SH, Savage KM, et al. Comparison between intraperitoneal and subcutaneous phencyclidine administration in Sprague-Dawley rats: a locomotor activity and gene induction study. Progress in NeuroPsychopharmacology \& Biological Psychiatry. 2008; 32: 414-422.

14] Hiramatsu M, Cho AK, Nabeshima T. Comparison of the behavioral and biochemical effects of the NMDA receptor antagonists, MK-801 and phencyclidine. European Journal of Pharmacology. 1989; 166: 359-366.

[15] Snell LD, Yi SJ, Johnson KM. Comparison of the effects of MK801 and phencyclidine on catecholamine uptake and NMDAinduced norepinephrine release. European Journal of Pharmacology. 1988; 145: 223-226.

[16] Balla A, Koneru R, Smiley J, Sershen H, Javitt DC. Continuous phencyclidine treatment induces schizophrenia-like hyperreactivity of striatal dopamine release. Neuropsychopharmacology. 2001; 25: 157-164.

[17] Balla A, Schneider S, Sershen H, Javitt DC. Effects of novel, high affinity glycine transport inhibitors on frontostriatal dopamine release in a rodent model of schizophrenia. European Neuropsychopharmacology. 2012; 22: 902-910.

[18] Del Arco A, Mora F, Mohammed AH, Fuxe K. Stimulation of D2 receptors in the prefrontal cortex reduces PCP-induced hyperactivity, acetylcholine release and dopamine metabolism in the nu- 
cleus accumbens. Journal of Neural Transmission. 2007; 114: 185193.

[19] Jackson DM, Johansson C, Lindgren LM, Bengtsson A. Dopamine receptor antagonists block amphetamine and phencyclidineinduced motor stimulation in rats. Pharmacology, Biochemistry, and Behavior. 1994; 48: 465-471.

[20] Kusljic S, Brosda J, Norman TR, van den Buuse M. Brain serotonin depletion by lesions of the median raphe nucleus enhances the psychotomimetic action of phencyclidine, but not dizocilpine (MK-801), in rats. Brain Research. 2005; 1049: 217-226.

[21] Aghajanian GK, Marek GJ. Serotonin, via 5-HT2a receptors, increases EPSCs in layer V pyramidal cells of prefrontal cortex by an asynchronous mode of glutamate release. Brain Research. 1999; 825: 161-171.

[22] Kitaichi K, Yamada K, Hasegawa T, Furukawa H, Nabeshima T. Effects of risperidone on phencyclidine-induced behaviors: comparison with haloperidol and ritanserin. Japanese Journal of Pharmacology. 1994; 66: 181-189.

[23] Mathé JM, Nomikos GG, Hildebrand BE, Hertel P, Svensson TH. Prazosin inhibits MK-801-induced hyperlocomotion and dopamine release in the nucleus accumbens. European Journal of Pharmacology. 1996; 309: 1-11.

[24] O'Neill MF, Heron-Maxwell CL, Shaw G. 5-HT2 receptor antagonism reduces hyperactivity induced by amphetamine, cocaine, and MK-801 but not D1 agonist C-APB. Pharmacology, Biochemistry, and Behavior. 1999; 63: 237-243.

[25] Kusljic S, Brosda J, van den Buuse M. Effects of haloperidol and clozapine on sensorimotor gating deficits induced by 5 hydroxytryptamine depletion in the brain. British Journal of Pharmacology. 2006; 147: 800-807.

[26] Kusljic S, Copolov DL, van den Buuse M. Differential role of serotonergic projections arising from the dorsal and median raphe nuclei in locomotor hyperactivity and prepulse inhibition. Neuropsychopharmacology. 2003; 28: 2138-2147.

[27] Kusljic S, van den Buuse M. Functional dissociation between serotonergic pathways in dorsal and ventral hippocampus in psychotomimetic drug-induced locomotor hyperactivity and prepulse inhibition in rats. European Journal of Neuroscience. 2004; 20: 3424-3432.

[28] Ervin GN, Birkemo LS, Nemeroff CB, Prange AJ. Neurotensin blocks certain amphetamine-induced behaviours. Nature. 1981; 291: 73-76.

[29] Kelly PH, Seviour PW, Iversen SD. Amphetamine and apomorphine responses in the rat following 6-OHDA lesions of the nucleus accumbens septi and corpus striatum. Brain Research. 1975; 94: 507-522.

[30] Pijnenburg AJ, Honig WM, Van Rossum JM. Inhibition of damphetamine-induced locomotor activity by injection of haloperidol into the nucleus accumbens of the rat. Psychopharmacologia. 1975; 41: 87-95.

[31] Staton DM, Solomon PR. Microinjections of d-amphetamine into the nucleus accumbens and caudate-putamen differentially affect stereotypy and locomotion in the rat. Physiological Psychology. 1984; 12: 159-162.

[32] Groenewegen HJ, Wright CI, Beijer AV. The nucleus accumbens: gateway for limbic structures to reach the motor system? Progress in Brain Research. 1996; 107: 485-511.

[33] Kesby JP, Eyles DW, McGrath JJ, Scott JG. Dopamine, psychosis and schizophrenia: the widening gap between basic and clinical neuroscience. Translational Psychiatry. 2018; 8: 30.

[34] McCutcheon RA, Abi-Dargham A, Howes OD. Schizophrenia, Dopamine and the Striatum: from Biology to Symptoms. Trends in Neurosciences. 2019; 42: 205-220.

[35] Clark D, Furmidge LJ, Petry N, Tong ZY, Ericsson M, Johnson D. Behavioural profile of partial D2 dopamine receptor agonists. 1. Atypical inhibition of d-amphetamine-induced locomotor hyperactivity and stereotypy. Psychopharmacology. 1991; 105: $381-$ 392.

[36] Schaefer GJ, Michael RP. Drug interactions on spontaneous locomotor activity in rats. Neuroleptics and amphetamine-induced hyperactivity. Neuropharmacology. 1984; 23: 909-914.

[37] Alsene KM, Fallace K, Bakshi VP. Ventral striatal noradrenergic mechanisms contribute to sensorimotor gating deficits induced by amphetamine. Neuropsychopharmacology. 2010; 35: 2346-2356.

[38] Ago Y, Nakamura S, Kajita N, Uda M, Hashimoto H, Baba A, et al. Ritanserin reverses repeated methamphetamine-induced behavioral and neurochemical sensitization in mice. Synapse. 2007; 61: 757-763.

[39] Auclair A, Blanc G, Glowinski J, Tassin J. Role of serotonin 2a receptors in the $\mathrm{D}$-amphetamine-induced release of dopamine: comparison with previous data on alpha $1 \mathrm{~b}$-adrenergic receptors. Journal of Neurochemistry. 2004; 91: 318-326.

[40] Meador-Woodruff JH, Mansour A, Healy DJ, Kuehn R, Zhou QY, Bunzow JR, et al. Comparison of the distributions of D1 and D2 dopamine receptor mRNAs in rat brain. Neuropsychopharmacology. 1991; 5: 231-242.

[41] Day HE, Campeau S, Watson SJ, Akil H. Distribution of alpha 1a-, alpha $1 \mathrm{~b}$ - and alpha 1d-adrenergic receptor mRNA in the rat brain and spinal cord. Journal of Chemical Neuroanatomy. 1997; 13: $115-139$.

[42] Darracq L, Blanc G, Glowinski J, Tassin JP. Importance of the noradrenaline-dopamine coupling in the locomotor activating effects of D-amphetamine. Journal of Neuroscience. 1998; 18: 27292739.

[43] Villégier A, Drouin C, Bizot J, Marien M, Glowinski J, Colpaërt F, et al. Stimulation of postsynaptic alpha1b- and alpha2adrenergic receptors amplifies dopamine-mediated locomotor activity in both rats and mice. Synapse. 2003; 50: 277-284.

[44] Drouin C, Blanc G, Villégier A, Glowinski J, Tassin J. Critical role of alpha1-adrenergic receptors in acute and sensitized locomotor effects of D-amphetamine, cocaine, and GBR 12783: influence of preexposure conditions and pharmacological characteristics. Synapse. 2002; 43: 51-61.

[45] Mitrano DA, Schroeder JP, Smith Y, Cortright JJ, Bubula N, Vezina $\mathrm{P}$, et al. A-1 Adrenergic receptors are localized on presynaptic elements in the nucleus accumbens and regulate mesolimbic dopamine transmission. Neuropsychopharmacology. 2012; 37: 2161-2172.

[46] Saigusa T, Aono Y, Uchida T, Takada K, Verheij MM, Koshikawa $\mathrm{N}$, et al., The $\alpha_{1^{-}}$, but not $\alpha_{2^{-}}$, adrenoceptor in the nucleus accumbens plays an inhibitory role upon the accumbal noradrenaline and dopamine efflux of freely moving rats. European Journal of Pharmacology. 2012; 688: 35-41.

[47] Hannon J, Hoyer D. Molecular biology of 5-HT receptors. Behavioural Brain Research. 2008; 195: 198-213.

[48] Gogos A, Kusljic S, Thwaites SJ, van den Buuse M. Sex differences in psychotomimetic-induced behaviours in rats. Behavioural Brain Research. 2017; 322: 157-166.

[49] Rivera-Garcia MT, McCane AM, Chowdhury TG, Wallin-Miller KG, Moghaddam B. Sex and strain differences in dynamic and static properties of the mesolimbic dopamine system. Neuropsychopharmacology. 2020; 45: 2079-2086.

[50] Gaytan O, Swann A, Dafny N. Diurnal differences in rat's motor response to amphetamine. European Journal of Pharmacology. 1998; 345: 119-128. 